\title{
Fostering Intermediate Class Efl Learners' Speaking Fluency in the Republic of Benin
}

\author{
EGOUNLETI Pédro Marius, IWIKOTAN Katchédé Etienne*, ZOUNHIN TOBOULA Martinien \\ Université d'Abomey-Calavi, Benin
}

*Corresponding Authors: IWIKOTAN Katchédé Etienne, Université d'Abomey-Calavi, Benin

\begin{abstract}
This study aims at finding out the effective techniques to improve EFL learners' speaking fluency in intermediate classes. In order to understand the main causes of learners' limited speaking fluency in Beninese secondary schools, two types of questionnaire were designed and administered to the respondents: the first type was administered to 113 EFL learners and the second one to 06 EFL teachers. In addition, four EFL teachers were interviewed and 02English classes were observed in order to check how speaking skills are taught, learnt and assessed. The analysis of the data revealed that the teaching of speaking is neglected by most EFL teachers in favor of other language skills. Moreover, learners' inability to speak English fluently is due to their negative perception of the language which, for them, constitutes a difficult subject to learn. This research suggests that learners be motivated to improve their own perception of English teaching and learning. The study also recommends self-training on the part of students by reading aloud and playing different roles in classroom conversational activities. Furthermore, educational authorities should provide schools with audiovisual materials to help teachers teach speaking skills adequately.
\end{abstract}

Keywords: Improve, Speaking, Fluency, Intermediate, Study

\section{INTRODUCTION}

\subsection{Problem Statement}

Human beings use language as one of the most important means of communication to meet their daily needs. People use not only their native languages but also foreign ones like English, Spanish, German, etc. to communicate with others. As far as the teaching and learning of English language are concerned, a large percentage of the world's language learners study English in order to develop proficiency in speaking (Richards and Renandya, 2002, p.201).Unfortunately, in the Republic of Benin where English is taught and learned as a foreign language, a large number of EFL learners are still unable to communicate in English language despite the recent government reforms and investments (Iwikotan, 2016,p.59).

This situation can be accounted for in many ways.. Firstly, the fact that English is a foreign language limits students' opportunities to practice it after class. Secondly, lack of qualified teachers and overcrowded classrooms are a major obstacle to an effective teaching and learning of English language in the Republic of Benin (Hindémé, 2019, p. 36). As a result, an ever-increasing number of EFL students complete secondary education and they are not in a position to sustain a one-minute conversation in the English language they had learnt for at least seven good years. (Iwikotan,2020,p.36)

In order to redress such a situation, the present study proposes to examine how speaking skills and fluency are taught and learnt in Beninese secondary schools in intermediate EFL classes.

\subsection{Purpose of the Study}

This study aims at improving Beninese secondary school intermediate EFL learners' speaking skills and fluency.

\subsection{Research Questions}

1) What are the causes of intermediate EFL learners' inability to speak English fluently?

2) How do EFL teachers motivate their learners to speak English fluently? 
3) What are the teaching strategies likely to improve EFL learners' speaking fluency?

\subsection{Significance of the Study}

This study is expected to help syllabus designers, methodologists, applied linguists and teachers to select effective teaching materials and techniques likely to develop EFL students' speaking skills and fluency in the process of designing, implementing and evaluating English curricula.

\subsection{Delimitations of the Study}

This study is limited to EFL intermediate learners in Beninese secondary schools and their teachers. It targets speaking fluency as a major dimension of speaking skills development.

\section{LITERATURE REVIEW}

This literature review is basically concerned with the definition of speaking skills, on the one hand, and the impacts of classroom speaking activities as well as teaching materials on speaking fluency development, on the other hand.

\subsection{Speaking Skill}

Speaking is one of the basic language skills. It is an important part of the five major language skills (listening, reading, speaking, writing and critical thinking). Thanks to it, learners can express themselves orally and learn how to use communicative skills in real life situations.

\subsubsection{Definition of Speaking}

Speaking is one of the most important aspects of language learning: people who know a language are referred to as speakers of that language. According to the Oxford Dictionary (2009, p. 414), speaking is "the action of conveying information or expressing one's feeling in a speech." Scholars do not have the same definition of speaking. As a result, Brown $(1994$, p. 19) considers it as "an interactive process of constructing meaning that involves producing, receiving and processing information."In other words, speaking is a give-and-take act of communication. In the same vein, Broughton (1980, p. 7) declares that "spoken language allows us to produce a sequence of vocal sounds, in such a way another person can reconstruct from those sounds a useful approximation to one original meaning."

In addition to that, Chaney (1998, p. 13) defines speaking as "the process of building and sharing meaning through the use of verbal and non-verbal symbols, in a variety of contexts." This definition implies that speaking is not limited to what comes out of the mouth but it also entails gestures and any other facial expressions. Furthermore, Jones (1989, p. 65) defines speaking as "a form of communication in which the effective conveyance of what the speaker says is very crucial."It means in a conversation situation, speakers have to make their utterances audible and understandable to the person they are talking to.

\subsubsection{Definition of Fluency}

According to the Oxford Advanced Learner's Dictionary (1998, p. 575),fluency is "the quality of being able to speak or write a language, especially a foreign language, easily and well." It means that, to be fluent, English learners have to speak easily and well without any difficulty. For Hughes (2002, p. 14) "it is the ability to express oneself in an intelligible, reasonable and accurate way without too much hesitation, otherwise the communication will break down because listeners will lose their interest." This definition is more interesting in the sense that it clearly shows that fluency and accuracy are closely knit together. Technically, the term fluency is a hypernym because it calls for a certain level of accuracy without which the message conveyed will not be understood. Hedge (2000, p. 54) adds that "the term fluency relates to production and it is normally reserved to speech. It is the ability to link units of speech together with facility and without strain or inappropriate slowness, or undue hesitation."

According to Harmer (2001, p. 69), "The ability to speak fluently presupposes not only knowledge of language features, but also the ability to process information and language on spot". Harmer's idea is that fluency calls for both linguistic knowledge and the ability to use that knowledge spontaneously to achieve communication. Given the importance of fluency in speaking, it is convenient to look at the ways in which fluency can be developed in EFL learners.

\subsection{The Roles of Audio-Visual Aids in Improving Speaking Fluency}


Audio-visual aids like movies, radio and music can help learners to improve their speaking fluency.

According to Kate (2000, p. 24), "For fluency to develop, the teacher must provide students with structured activities and discussion used in combination with videotaped materials." Through this idea, Kate urges English teachers to expose their students to video clips or movies in order to enable them to listen to the film dialogue first and then to answer the questions which had previously been written on a sheet of paper. After that part of the work, teachers will give students time to discuss about the key events which took place in the given movies.

For $\mathrm{Hu}$ (1997, p. 47), "the only thing you need is a good quality radio. Then you can receive varied programs on VOA with authentic American pronunciation." By listening to radio channels like BBC, VOA, learners' fluency can improve because of their exposure to authentic language.

Another audio element worth mentioning is music playing which is a valuable activity the English teacher can implement in his classroom. According to MalgorzataJedynak (2000, p. 30), "music promotes conversation because listeners may interpret the same piece of music differently. Music makes people act spontaneously, not only on a dance floor but also in a classroom." It follows from this quotation that music can give rise to spontaneous conversation in the classroom because of the fact that different individuals interpret it in their own ways. However, this is easier said than done. For music to fulfill that role adequately, teachers need to select it carefully and plan activities likely to prompt discussions in the classroom.

All in all, the use of audio-visual materials is a very important tool for improving speaking fluency.

\section{Methodology OF THE STUdY}

\subsection{Research Design}

This work used quantitative and qualitative research methods. Therefore, three data collection instruments were used for triangulation purposes: questionnaire, interview, and classroom observation.

\subsection{Research Setting}

The present study focuses on the EFL intermediate learners in Dogbo secondary school located in an urban area. Some students attending this school come from villages located a few miles away from Dogbo. Therefore, the EFL students involved in this research are from diverse backgrounds, which can influence in one or the other their learning.

\subsection{Research Population}

The present study attempts to investigate the causes of EFL learners' inability to speak English fluently as well as the ways and the means to address efficiently this situation. The research population of this study is made up of teachers of English and their students at Dogbo secondary school during the first semester of the academic year 2019-2020.

\subsection{Sampling}

Six (06) EFL teachers and one hundred and thirteen (113) students were randomly selected at Dogbo secondary school to participate in the study.

\subsection{Data Collection Procedures}

Burns (1999 p. 71) stated that there are three principles in the ethical conduct of Action Research: "Negotiation, responsibility and confidentiality."Therefore before starting the data collection, the researchers introduced themselves, requested permission from the school administrators, explained the research objectives to the teachers and reassured them that the questionnaire is anonymous.

The school administrators allowed the researchers to attend the EFL teachers' weekly meeting. At the end, the researchers explained the objectives of their studies and almost all the teachers accepted to participate. On the spot, six (6) randomly selected teachers received 6 (six) teacher questionnaire sheets and 113 samples of the questionnaire sheets designed for their EFL learners. Four (4) other teachers agreed to be interviewed the week after and two (2) teachers invited the researchers to observe their EFL classes. Thanks to the EFL teachers' active participation, the procedure went 
smoothly and all the questionnaire sheets administered were returned. Therefore, the return rate was $100 \%$.

\subsection{Description of Data Collection Instruments}

The three (3) data collection instruments were constructed to collect information to answer the three(3)research questions.

The questionnaire addressed to EFL learners contain nine (9) items whereas the questionnaire designed for EFL teachers included six (6) items.

During the interview with EFL teachers, three (3) important questions were asked:

a) Why do EFL students neglect English language learning?

b) What are the reasons for EFL students' inability to speak English fluently?

c) How can EFL learners' speaking fluency be improved?

The classroom observations focused on three major preoccupations:

- Techniques used by EFL teachers to make their learners speak English language fluently

- Causes of EFL students' inability to speak English fluently

- How students are assigned activities

\subsection{Methods of Data Analysis}

The data analysis consisted in determining frequencies and percentages were calculated where appropriate. Figures and tables were also designed to present the data.

\section{Presentation and Discussion of the Findings}

\subsection{Presentation of the Findings}

The presentation of the findings includes the analysis of data from the learners' questionnaire, the teachers' questionnaire, the interview and classroom observations.

\subsubsection{Data from the Questionnaire Administered to EFL Learners}

One hundred and thirteen (113) EFL learners answered the questions on the questionnaire sheet during the study. Below are the tables and figures that display their answers.

Table1. Level of English Speaking

\begin{tabular}{|l|l|l|l|}
\hline Item & Answer & Frequency & Percentage \\
\hline Fluency during & - Yes & 00 & $00 \%$ \\
conversations in English & -No & 113 & $100 \%$ \\
\hline
\end{tabular}

Table 1 shows that none of the respondents is able to speak English fluently during conversations. This indicates that the learners are aware that their proficiency in English is limited.

The second item was to find out if the respondents practice English conversation in pairs or in groups.

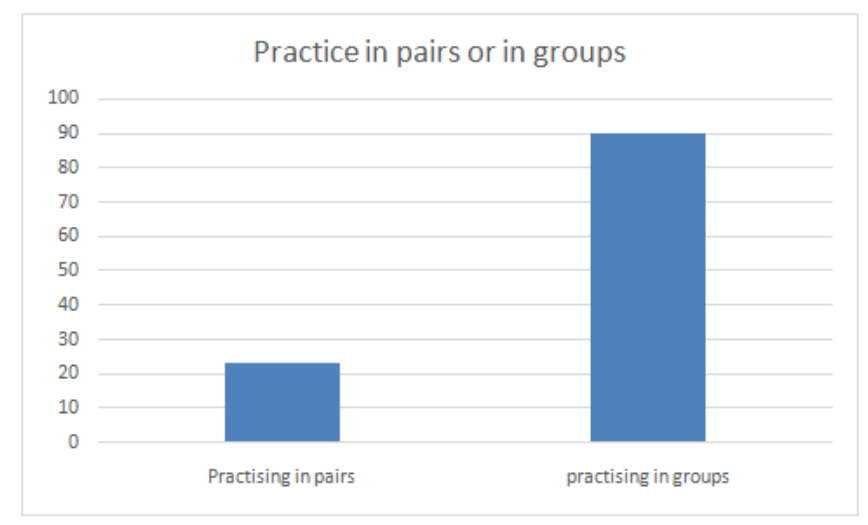


Figure1. Speaking English in pairs or in groups

According to Figure 1, 20.32\% of the respondents reported that they practice English conversation in pairs whereas $79.64 \%$ practice in groups. These data show that teachers prefer putting students in groups to practice conversation rather than in pairs. Depending on the group dynamics, some students may not have the opportunity to practice at all because some of their group mates may be vocal and monopolize the floor if left unchecked. When the respondents were sounded out on the reasons why they learn English at school, an overwhelming majority (85\%) indicated that they learn English in order to get marks while the remaining $15 \%$ stated that they learn the language in order to be able to communicate in it.

That is probably the reason why all the EFL learners investigated are not able to communicate fluently in English language as indicated in Table 1.

One of the reasons why most of the learners reported that they learn English just to get grades is that they do not practice speaking very often in class as shown in Figure 2 below.

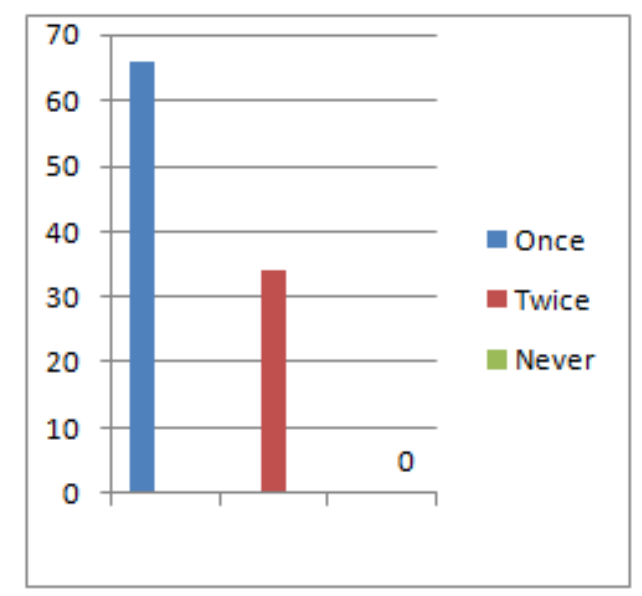

Figure2. Performance of speaking activities with EFL students

Figure 2 indicates that $66 \%$ of the learners perform speaking activities once a week whereas $34 \%$ do so twice a week. With these results, the students cannot develop speaking fluency because they are not provided with the opportunity practice speaking in the classroom very often. On the other hand, when the respondents were requested to express their feelings with regard to speaking activities, $65 \%$ of them reported that speaking activities are interesting as shown in Figure 3 below.

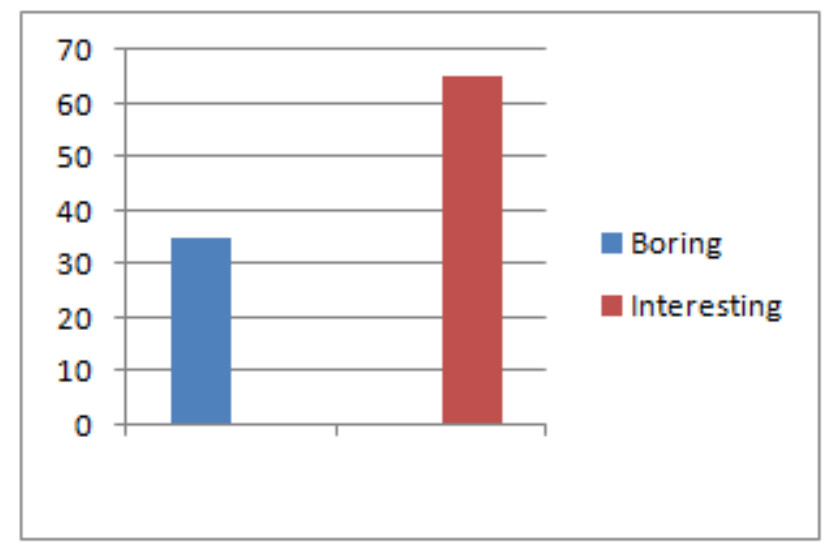

Figure3. Students' Appreciation of English Language Speaking

Table3. Speaking Fluency development strategies

\begin{tabular}{|l|l|l|l|}
\hline Question & Answer & Frequency & Percentage \\
\hline $\begin{array}{l}\text { Developing speaking } \\
\text { fluency }\end{array}$ & $\begin{array}{l}\text {-Read English books } \\
\text {-Do a lot of speaking activities in the } \\
\text { classroom }\end{array}$ & 45 & $40 \%$ \\
\hline
\end{tabular}


To become fluent in English speaking, $40 \%$ of learners think that they need to read English books whereas $60 \%$ of them indicate that they need to perform a lot of speaking activities in class. These results show that EFL learners need to perform more speaking activities in order to improve their speaking fluency. The respondents' opinions about other activities likely to improve fluency are expressed in Table 4 below.

Table4. Speaking Activities Likely to Develop Fluency

\begin{tabular}{|l|l|l|l|}
\hline Question & Answer & Frequency & Percentage \\
\hline $\begin{array}{l}\text { Activities likely to improve } \\
\text { fluency }\end{array}$ & -Learn English songs & 33 & $29 \%$ \\
& -Listen to English-speaking media & 00 & $00 \%$ \\
& -Watch films with written translations in & & \\
& English & 80 & $71 \%$ \\
\hline
\end{tabular}

A small proportion (29\%) of learners think that learning songs can help to improve fluency whereas $71 \%$ believe that watching films with written translations in English can develop fluency. It is surprising that none of the learners thought of listening to English-speaking media as a way of improving fluency. Listening to such media would provide learners with role models to imitate in terms of fluency. However, their responses here are corroborated by their responses to the item on the use of audiovisual materials for practicing English. In fact, $60 \%$ of the respondents never use such materials while only $40 \%$ reported that they use those materials sometimes. In the same vein, all the respondents reported that they never listen to BBC or other channels that broadcast in English. This may be due to the fact that learners are not aware that with a small radio they can receive BBC and other English-speaking channels on Frequency Modulation (FM).

\subsubsection{Questionnaire Administered to EFL Teachers}

The qualifications of the six (6) English teachers that completed the questionnaire are displayed in Figure 4 below.

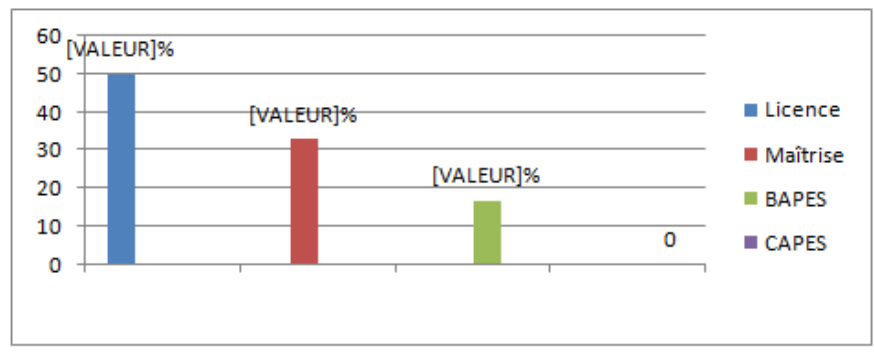

Figure4. EFL Teacher Qualification

These results show that among the six (6) teachers who answered the questionnaire, $50 \%$ got a "licence" (a three-year university degree), 33\% helda "Maîtrise" (a four-year university degree), 17\% held BAPES(a Professional Teacher Training degree)but none of them got "CAPES" (Advanced Teacher Training Degree). This shows that most of EFL teachers are not qualified for the teaching profession. This situation cannot allow them to teach their EFL learners with the appropriate teaching techniques or strategies. That is certainly the reason why all six of them reported that they do not motivate their learners.

Table6. Teachers' satisfaction with their EFL Learners' Oral Production

\begin{tabular}{|l|l|l|l|}
\hline Question & Answer & Frequency & Percentage \\
\hline Satisfaction with learners' oral production & - Yes & 00 & $00 \%$ \\
& - No & 06 & $100 \%$ \\
\hline
\end{tabular}

Table 6 shows that none of the respondents are satisfied with their learners' oral production. Therefore, EFL teachers are aware of their students' difficulties in English. The question is now to know what they do to help their learners overcome such difficulties. The answers to that question are displayed in Figure 5. 


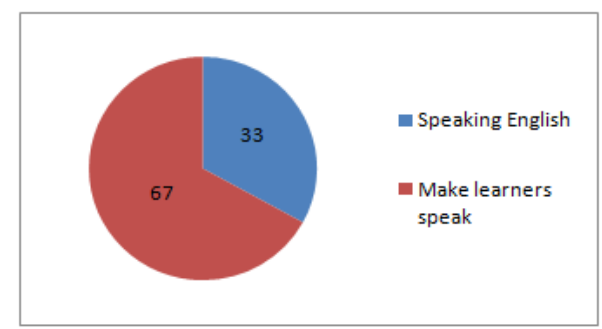

Figure5. Teacher's effort to help their learners to speak English

These results highlight that $33 \%$ of the teachers speak English frequently in class whereas $67 \%$ of them make learners speak English a lot in class. Teachers need to speak more English in class so that learners can imitate them. Apart from speaking English in class, teachers use other techniques to improve their learners' speaking skill as shown in Figure 6.

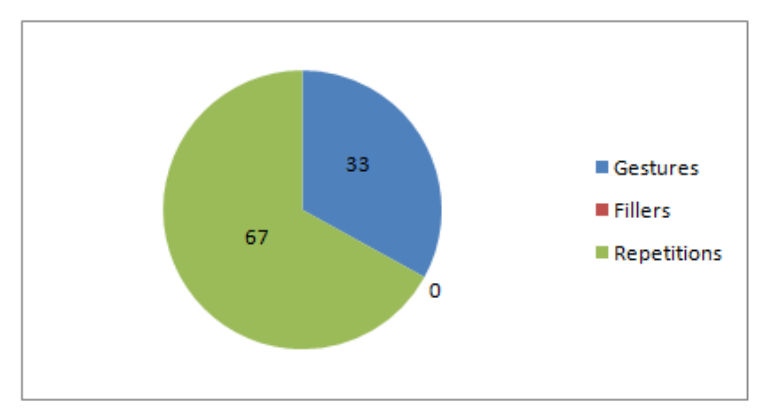

Figure6. Techniques Used by Teachers to Develop their Students' Fluency

With these results, $33 \%$ of the teachers use gestures to teach whereas $67 \%$ use repetitions. However, none of them use fillers. The results underpin the fact that EFL teachers try their best to help learners develop their speaking skill by using a variety of strategies and techniques. Unfortunately, all the respondents reported that they do not use audiovisual materials to teach speaking, which implies that they do not teach listening comprehension with authentic materials. Without mainstreaming audiovisual materials in their teaching, it will be difficult for learners to develop fluency in speaking as they will not have native speakers to try to imitate.

\subsubsection{Results of the Interviews}

The first question asked to teachers aims at investigating the reasons why they neglect speaking activities while teaching English. Some of the respondents answered that they do not neglect such activities as they try their best to get their learners to practice speaking. At the same time, those respondents acknowledged that they spend more time teaching writing. Other respondents also stated that they do teach speaking but their students are neglectful and do not take that skill seriously. Even when the learners are encouraged to practice speaking in groups, they spend their time speaking local languages and French, which is not conducive to the development of speaking.

The second question was asked to find out the causes of the intermediate learners' inability to speak English fluently. The first teacher says, "It is because learners have in their mind that only writing can help them to get marks and go up without knowing that the speaking is also necessary for them". What transpires here is the learners' belief that they are learning the language just to pass examinations and not for real-life communication purposes. Another teacher argued that "the fact that most of EFL classes are overcrowded is seriously affecting learners speaking fluency because the majority of them do not get the opportunity to speak English neither with the teacher nor with their classmates before the class ends. Therefore, because they are so many, it becomes difficult for teachers to take care of each student. Speaking is a productive skill and the large number of students in EFL classes does not enable teachers to have enough practice with each of the learners. The over crowdedness creates a situation in which a student can attend many classes without having the opportunity to interact with the teacher or classmates. Another respondent added that "While some are following the course, others are not concentrated." Lack of concentration is another reason why students are not unable to speak English fluently because when they do not follow the lessons carefully, the level of input they receive is very low. Without enough input, it is difficult to speak fluently. One last teacher declared that "learners consider English language as a difficult language to learn and so they neglect it". Sometimes, when it is time for English language class some students 
become anxious whereas others miss it. They also think that other subjects are more important for their academic success than English.

The third question tries to explore what teachers can do in order to improve the learner's speaking fluency. To this question, one of the respondents answered that 'It is important to use communicative strategies like playing games (storytelling, dialogue...) and also motivate learners to speak English language in the classroom and even out of schools.' This respondent encourages the use of the communicative language teacher method and the practice of speaking outside the classroom even though no details have been provided on who the learners are going to practice speaking with. Another respondent stated that "learners need to keep a vocabulary notebook; practice speaking with other English learners, watching video chat and also watch an English video clip every day. "For this respondent, developing their vocabulary by keeping notebooks and watching videos in English can enable learners to improve their fluency in English.

\subsubsection{Results of the Classroom Observations}

During the teaching time, teachers spoke slowly so that learners could hear what they are saying. To help their learners understand the lesson, some teachers resorted to the French language from time to time. They also used gestures to explain the lessons. Nevertheless, we noticed that learners could hardly answer some of the questions asked by the teachers. While some learners were ashamed of speaking, some succeeded in speaking the language well.

We did not witness any use of audiovisual materials in any of the classrooms observed. The working conditions were far from ideal. The classrooms we visited were overcrowded. One of them included as many as 80 students, which poses a serious challenge to the teacher in terms of developing learners' fluency. In some cases, furniture was lacking to the extent that a bench made for two students would accommodate four.

\subsection{Discussion of the Findings}

The discussion of the findings aims at answering the research questions of this study.

\subsubsection{The causes of Learners' Inability to Speak English Fluency}

As the first research question attempts to unravel the causes of Beninese EFL intermediate learners' incapacity to speak English fluently, the analysis of the data collected has helped to identify four (4) major reasons: EFL learners and teachers' perception about language teaching and learning, lack qualified EFL teachers, difficult working and living conditions of both teachers and learners, unfavorable linguistic environment which does encourage students to practice the language.

Indeed, EFL learners' inability to speak English fluently is partlybecause $30 \%$ of the students investigated have a negative perception of English learning as they view English as a difficult subject to learn (Table 2).In addition, 85\% of the students declared that they learn English not to speak it fluently but to get good marks during evaluations (Figure 2); the communicative purpose of language learning is utterly neglected by students.

Moreover, the data collected seem to indicate that EFL teachers are partly responsible for their students' inability to speak English. Figure 3 shows that a large majority of the teachers working in Beninese secondary schools are not qualified for the teaching job; 50\% of them are Licence (a threeyear degree) holders whereas 33\% hold a Maîtrise which is a four-year degree in English; only 17\% of them had been trained for the teaching job in a teacher-training school. As a result, none of the respondents used audiovisual materials on a regular basis. Besides, the respondents do not often include enough speaking activities in their daily teaching practices as shown in Figure 4which indicates that $66 \%$ of learners are taught speaking once a week whereas $34 \%$ of them are taught speaking twice in a week. Under such circumstances, it is difficult to expect students to develop effective speaking skills and fluency.

Another cause of EFL learners' inability to speak the English language fluently is closely related to both EFL teachers and learners' difficult living and working conditions. Data collected during the interviews and classroom observations indicate that there is lack of furniture and over crowdedness of the classrooms. In addition, the respondents do not make use of audiovisual materials during their English language teaching to improve their learners' speaking fluency. All these results validate the findings of Baker and Westrup (2003, p. 12) who stated that "Barriers to teaching and learning can occur if knowingly or unknowingly teaching and learning take place in culturally, pedagogically, technically and socially unfavorable conditions." The technical and pedagogical conditions witnessed 
during the investigations are not conducive to the development of fluency in an EFL context like Benin.

\subsubsection{Strategies for Motivating EFL Intermediate Learners to Speak English}

The data collected with both EFL teachers and learners suggests three major ways of motivating EFL learners to speaking the English language:

-Use audiovisual materials

- Regular use of classroom communicative activities

-Establishment of a friendly and less stressful classroom atmosphere

Motivation is an essential aspect of English language teaching and learning. Unfortunately, EFL teachers in Beninese secondary schools scarcely motivate their learners to speak English. The results in Table 5 show that $100 \%$ of teachers investigated do not take time to motivate learners to speak the English language fluently; as a result, most of the learners are unable to speak English. This result is in line with Luoma's idea that "motivation is the objective and the end of any successful teaching and learning process without which no real progress is possible." (Luoma, 2004, p. 01).To this end, the data collected during the interviews with EFL teachers revealed that all of them(100\%) suggested using audiovisual materials in teaching EFL in order to motivate students to speak the English language fluently. For instance, teachers can expose their learners to video clips, songs or movies in order to increase the input they receive in terms of accent, vocabulary and fluency and encourage them to speak the language like native speakers.

Another way of encourage learners to speak English is to make EFL classes more communicative. Results in Figure 3recommend teachers to motivate their learners through communicative activities that promote student interactions and oral communication. This finding corroborates the conception of Donnley(2004,p. 24) who supports that "for fluency to develop, teachers must provide students with communicative activities used in combination with videotaped materials."According to Malgozata (2000, p. 87) "Music makes students act spontaneously in classrooms and out of schools. It promotes conversation because listeners may interpret the same piece of music differently."

Besides, making an English classes learner-friendly and stress-free is an effective way to motivate learners to develop speaking skills. This finding is buttressed by Egounléti and Hindémé $(2018$, p....) who posited that "anxiety is significantly reduced, and interactions are increased in a classroom when learning occurs in a friendly teaching atmosphere."

\subsubsection{The Teaching Strategies to Improve EFL Learners' Speaking Fluency}

As far as the strategies to improve EFL learners' speaking fluency are concerned, the use of audiovisual materials has emerged as the most recurrent suggestion from both teachers and students. In fact, the use of audio-visual materials has proven effective for improving EFL learners' speaking fluency. By using audiovisual materials, both hearing (ears) and vision (eyes) are involved. During their speaking class, EFL teachers need to use television programs, video films, motion pictures, computers and so on (Table 7).According to Freeman (1981, p...), "The necessary practice is thought to be most successful when students are engaged in the meaningful exchange of information rather repeating a teacher's model."So, through speaking activities combined with audiovisual materials, learners are engaged in different types of interactions that develop their speaking fluency because asFreeman (1981,p. 67) put it, "It appears that the goal of many language teachers is to prepare their students to communicate in English."

In order to help students achieve fluency, another strategy which emerges out of the data collected is to give learners time to relax while speaking. Stress is for the respondents an obstacle to fluency. In addition, as it is recommended in table 4,learners must be taught some English songs and watch films with written translations in English. The results displayed in Table 8 suggest the use of gestures and repetitions as a strategy for developing student speaking skills and fluency in EFL classes. Table 3 puts an emphasis on the fact that teachers need to encourage their students to read books and to get involved in classroom speaking activities.

\section{CONCLUSiON}

This research work helps to understand the major causes of EFL students' inability to speak English fluently in the Beninese context. After exploring the literature related to the topic, two types of questionnaire were designed and administered to both teachers and students; interviews and classroom observations were also conducted with the active involvement of teachers and learners. The data 
collected and analyzed reveal that Beninese intermediate EFL learners have a negative perception of the English language learning which, according to them, helps to get good marks during their various evaluations and examinations. The findings also reveal that EFL teachers' lack of professional training is a major obstacle to a sound development of students' communicative skills and fluency. In order to help learners speak the English language fluently, both EFL teachers and learners agree on the use of a variety of strategies such as communicative games and audiovisual materials. Teachers must also motivate their learners to speak English in the classroom and even beyond the schools. As far as the learners are concerned, they need to keep a vocabulary notebook and practice speaking their peers.

\section{REFERENCES}

[1] Baker, J. and Westrup.H. (2003).Essential Speaking Skills: A Handbook for English Language Teachers. London: Continuum International Publishing.

[2] Broughton, D. (1980). Teaching English as a Foreign Language. London: Rutledge education books.

[3] Brown, D. (1994). Principles of Language Learning and Teaching. Printice Hall, Regents Englewood Cliffs.

[4] Burn G.(1997).Research Methods in Education.(1997).New York:New York University Press

[5] Channey, L. (1998). Teaching Oral Communication. In Grandes K-8.Boston: Allyn and Bacon.

[6] Freeman, D. L. A. (1981). Journal for the Teacher of RP English Forum US. Oct 1987. $24 / 4$.

[7] Hadfield, J. (1996). Advanced Communication Games. England: Addison Wesley Longman Limited.

[8] Harmer, J. (2001).The Practice of English Language Teaching. Pearson Education: Longman.

[9] Hedge, T. (2000). Teaching and Learning in the Language Classroom. Oxford: Oxford University Press.

[10] Hu B. (1997). Fostering Students' Speaking Skills and Fluency: Cambridge: Cambridge University Press.

[11] Egounléti,P. and Hindémé U.(2018). Seating Arrangement as a Means for Improving Interactions in EFL Beginner Classes:the Case of some Secondary Schools in Littoral Region. International Journal on Studies in English Language and Literature, 6(10),31-46.

[12] Hughes, R. (2002). Teaching and Researching Speaking. Pearson Education: Longman.

[13] Iwikotan, E. (2016). Critical Appraisal of Secondary School English

[14] Curricula in Benin.Glienicke: GaldaVerlag.

[15] Jones, Rhodri. (1989). Speaking and Listening. London: John Murray Publishers Ltd.

[16] Kate S.(2000).Teaching Fluency and Accuracy in Language Classes. London: New Publishers

[17] Luoma, S. (2004).Assessing Speaking. Cambridge: Cambridge University Press.

[18] Oxford Advanced Learner's Dictionary.(1948). Oxford University Press.

[19] Oxford Dictionary of Current English.(2009). Oxford University Press.

[20] Morrison R. (2002). Evaluating Communicative Activities in Interactive Classes. New York: Birds Press

[21] Malgorzata T.(2000).New Dimensions of Teaching Speaking Skills. Oxford: Oxford University Press

[22] Richards and Renandya (2002).Teaching Listening and Speaking: From theory to practice. New York: Cambridge University Press.

\section{AUTHORS' BIOGRAPHIES}

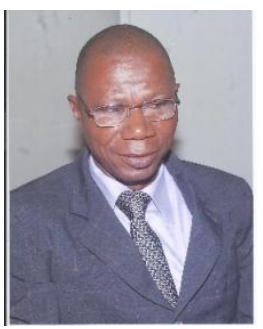

Dr. Katchédé Etienne IWIKOTAN, is a lecturer and researcher (Assistant Professor) at the English Department, Université d'Abomey-Calavi, Benin (West Africa). He is also a conference interpreter and a certified translator. He taught at secondary school level for 20 years before moving to the university six years ago. His research interests are assessment, EFL teachers' professional development, corpus linguistics, EFL learner motivation, and the teaching of the four (listening, speaking, reading, and writing) skills as well as grammar and vocabulary. Finally, he holds a PhD from Université d'Abomey-Calavi in Benin and a Master of Education (Higher Education Administration) from Loyola University Chicago in the United States of America.

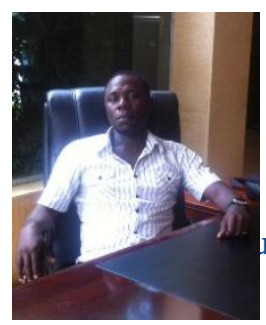

CoffiMartinien ZOUNHIN TOBOULA, is an Assistant Professor at the Department of Literature, Languages, Arts and Communication (FLLAC) of the University of Abomey-Calavi (UAC). Holder of a $\mathrm{PhD}$ in Linguistics and Didactics of the English language, his areas of interest are psycho-pedagogy, learner 
psychology, anxiety management, promotion of oral communication and leadership, promotion of extracurricular activities, and innovation of teaching and research techniques in TEFL. Competent communicator and member of Toastmasters International, he is a promoter and charter member of several English language learning circles including the Universal Toastmasters Club of Cotonou. Freelance translator and interpreter, he is also in charge of the management of a language laboratory and passionate about writing and research in human psychology

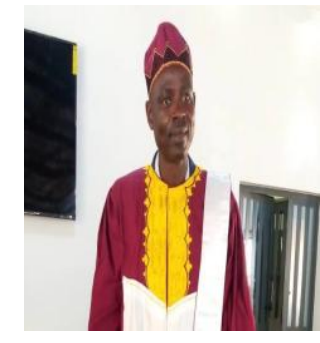

Dr.Pédro Marius EGOUNLETI, was born on 12th January 1976 in Niamey (Niger). He is currently Assistant Professor, Lecturer of EFL Didatics and business administration at English Department of University of Abomey Calavi, Bénin, West Africa.

Citation: IWIKOTAN Katchédé Etienne, et.al. "Fostering Efl Learners' Speaking Fluency in the Intermediate Classes in the Republic of Benin" International Journal on Studies in English Language and Literature (IJSELL), vol 9, no. 2, 2021, pp. 9-19. doi: https://doi.org/10.20431/2347-3134.0902002.

Copyright: (c) 2021 Authors. This is an open-access article distributed under the terms of the Creative Commons Attribution License, which permits unrestricted use, distribution, and reproduction in any medium, provided the original author and source are credited. 